\title{
CREATING A SAFE SCHOOL FOR CHILDREN AND TEACHERS TO TEACH THEM TO BECOME SMART AND COMPETITIVE HUMAN RESOURCES
}

\author{
Anak Agung Gede Agung \\ Educational Management, Ganesha Education University \\ Email: agung2056@undiksha.ac.id
}

\begin{abstract}
Vary of violances occurred in schools (e.g. Tabanan case in 2014 and Makasar case in 2016) showed us of how school has no longer been a safe and friendly place for teachers and students as well. Indonesian Law 20/2003 art. 3 stated that the national education functions to develop the capability, character, and civilization of the nation for enhancing its intellectual capacity, and is aimed at developing learners ' potentials so that they become persons imbued with human values who are faithful and pious to one and only God; who possess morals and noble character; who are healthy, konwledgeable, competent, creative, independent; and as citizens, are democratic and responsible. To address the objective of national education there must be a safe and friendly school climate, both physically and psychologically. The term 'safe and friendly school climate' here reffers to a peaceful atmosphere where the teachers, staff, and students are free from all fear and dangers (BNPB, 2011). In other words, a safe and friendly school refers to educational institution in which all the members (teachers, staff, and students) are free from dangers both internally and externally (Kemendikbud, 2016). In order to have 'a safe and friendly school' for all, the following efforts should be taken seriously into mind: (a) teachers should have adequate competences, both personal, pedagogyc, professional, and social; (b) there is need for building up a communication forum (e.g. PGRI, MKKS, MGMP, KKG, IGTK) for all stakeholders to communicate and to help each other in resolving the problems; and (c) there is also a need to develop localwisdom based management in order to have a character and
\end{abstract}

harmonious school.

Keywords : Safe school, violances, school climate

\section{INTRODUCTION}

Recently quite a number or people talked about a safe school AND It is generaly understood that schools have tobe able to give safe and comfortable feelings, physically and psychologically, to the students. Still fresh in our minds some occurrances of student harassments and also teacher harassments. The case of Pak Kasi, a headmaster who had to contact an authority because of punishing his student (1980s). The case of a teacher hitting of a student in Payangan (around 2013s), the case of physical punishment by ordering students to stand in front of the classroom in one of junior high schools in Tabanan (around 2014s), and the most recent one is the case of a student's parent harassing a public vocational school teacher in Makassar, south Sulawesi (August 2016).

\section{DISCUSSION}

A. Smart and Competitive Human Resources In Act No. 20 Year 2003 on National Education System (Sisdiknas) it is clearly stated that national education serves a function to develop ability and build character and civilization of the nation that has dignity, and is aimed at developing the potentialityity of the student to become a faithful person who is resigned to God,

has a good conduct, is healthy, learned, capable, creative and autonomous, and to become a democrtic and responsible person (article 3 Act 20 year 2003). To realize these aims, the Ministry of Education and Culture has decided the vision that in 2025 it is capable of making Smart Indonesian Citizens (SIC) and Competitive Indonesian Citizens (IICK) become realities.

After the launching of reformation in 1998, the centralistic government system became a government system that is decentralistic and regionally autonomous. This autonomous government system needs smart, dynamic, and competitive human resources to be able to compete with other nations in the globalization era. Hence, according to [1] the young generation who will be responsible for the survival of our nation is required to possess a correct understanding about how they should show their attitude toward the life struggle so that later on they will not become the burden of the nation, society, and family. The characteristics of a Smart and Competitive Person are presented in the following matrix.

\begin{tabular}{|ll|lr|}
\hline 1. & $\begin{array}{l}\text { Spiritual } \\
\text { Intelligence }\end{array}$ & $\begin{array}{l}\text {.Actualizing } \\
\text { through } \\
\text { management }\end{array}$ & $\begin{array}{r}\text { oneself } \\
\mathrm{sp} \text { [iritual }\end{array}$ \\
\hline 2. & $\begin{array}{l}\text { Emotional } \\
\text { and Social } \\
\text { Intelligence }\end{array}$ & $\begin{array}{l}\text { 1. Actualizing } \\
\text { through } \\
\text { management }\end{array}$ & $\begin{array}{r}\text { oneself } \\
\text { emotional }\end{array}$ \\
to
\end{tabular}




\begin{tabular}{|c|c|}
\hline & $\begin{array}{l}\text { increase sensitivity } \\
\text { toward the fineness } \\
\text { and beuty of arts and } \\
\text { culture, as well as } \\
\text { competency to express } \\
\text { them. } \\
\text { 2. Actualizing oneself } \\
\text { through social } \\
\text { interaction which (a) } \\
\text { develops and foster } \\
\text { reciprocal relations; (b) } \\
\text { democratic relation; (c) } \\
\text { emphatic and } \\
\text { symphatic relations; (d) } \\
\text { respecting human } \\
\text { rights; (e) happy and } \\
\text { self confident; (f) } \\
\text { respecting plurality in } \\
\text { society and nation; (g) } \\
\text { having nationality } \\
\text { insight with an } \\
\text { awareness of one's } \\
\text { rights and } \\
\text { responsibilities to the } \\
\text { nation. }\end{array}$ \\
\hline $\begin{array}{l}3 . \\
\text { Intellectual } \\
\text { Intelligence }\end{array}$ & $\begin{array}{l}\text { 1. } \begin{array}{l}\text { Actualizing } \\
\text { through reasolf } \\
\text { management to get } \\
\text { competencies and }\end{array} \\
\text { autonomy in science } \\
\text { and technology. } \\
\text { 2. Actualizing critical, } \\
\text { creative, innovative, } \\
\text { and imaginative } \\
\text { intelligence. }\end{array}$ \\
\hline $\begin{array}{ll}\text { 4. } & \text { Kinesthetic } \\
\text { Intelligence }\end{array}$ & $\begin{array}{l}\text { Actualizing oneself through } \\
\text { physical management to } \\
\text { become healthy, fit, } \\
\text { enduring, responsive, } \\
\text { skillful, and swift. }\end{array}$ \\
\hline $\begin{array}{l}\text { 5. Competitive } \\
\text { Person }\end{array}$ & $\begin{array}{l}\text { 1. having strong } \\
\text { personality and like to } \\
\text { become the best. } \\
\text { 2. having a high spirit of } \\
\text { competition } \\
\text { 3. autonomous } \\
\text { 4. never give up } \\
\text { 5. makes and develop } \\
\text { networking } \\
\text { 6. friendly toward change } \\
\text { 7. innovative and become } \\
\text { agent of change } \\
\text { 8. productive } \\
\text { 9. aware of quality } \\
\text { 10. oriented toward } \\
\text { something global } \\
\text { 11. long life education } \\
\text { 12. become blessing for all }\end{array}$ \\
\hline
\end{tabular}

The description about globalization and its relation to preparing smart and competitive human resources are visualize in figure 1 . In figure 1 it is explained that to face globalization challenges, one needs high quality (smart) human resources with high competitiveness.

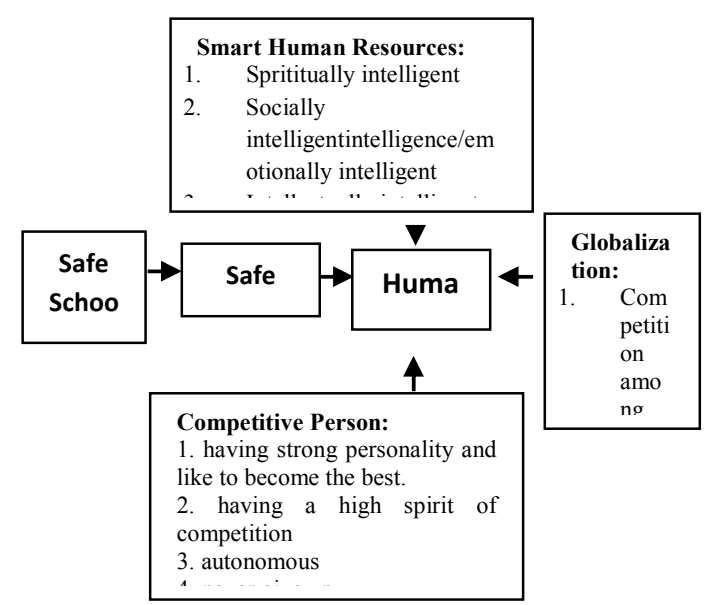

B. Review on the Existance of Children as Students

A person (student) is a creature who grows and develops according to his/her potentiality. A child's psychological development can develop towards positive and negative directions. Therefore, it is a duty of the teacher to orient the child towards the positive development [2]. In relation to child's potentiality development, there are several psychological theories which state that the nature or existance of a child is as follows.

1. Mental faculty psychology

a. Fasculty Psychology

An individual has several faculties/strengths such as: to recognize, to remember, to respond, to think, to dream, to feel, to evaluate, and to do something. These faculties are developed through a repetitive exercises.

b. Response Psychology (Vorstellungen)

It is also called herbatism, since it was introduced by Herbart. This theory states that every experience that an individual gets through various senses will be stored and give impressions in conscience. These impressions will appear again in the form of responses.

c. Romantic Naturalistic Psychology -> Rousseau

An individual has got the potentiality to develop. Through a various learning activities, children will develop all the potentialitys that they have. Teachers do not need to force children to learn, but need to provide instructional materials which can 
attract attention and interest, according to the needs and development, to create joyful environment, to give guidance and motivation according to the childrens' characteristics and nneds. The concept of students active learning, problem solving, inquiry, etc.-> refer to romantic naturalistic psychology.

2. Behaviorism Psychology

a. Association/connetionism Psychology

Proponent:Thorndike

This theory states that an individul behavior is a relationship between a stimulus and a response. Thorndike points out three principles/laws of learning, that is:

Law of readiness $->$ law of readiness in learning

Law of exercise $->$ law of exercise in learning Law of effect $->$ law of the usefulness of learning achievement

b. Conditioning Psychology -> Pavlov

An experiment with a dog with saliva due to stimulus conditioning in the form of bell that rings and food that the dog sees. According to this theory learning is an attempt to condition the shaping of behavior or response to something so that the behavior become a habit.

c. Operant Conditioning Psychology $->$ Skinner

$\rightarrow$ This theory is the development of association/connectionism and conditioning

$\rightarrow$ If in the conditioning theory, the thing that is given condition is its stimulus. While in opperant conditioning, the one that is conditioned/reinforced is its response.

3. Gestalt Cognitive Psychology

a. Cognitive Psychology

$\rightarrow$ This theory stresses on the knowing process that is: finding scientific methods in learning the mental process that is involved in an effort to seek and find knowledge.

$\rightarrow$ The instruction which is based in this theory stresses on active learning process, especially active in terms of moral/mental (thinking process) in seeking and finding knowledge and using it.

Examples: discussion, research, problem solving, educative, inductive, etc.

b. Field Psychology

$\rightarrow$ This theory stresses on the wholeness and integretion.

According to this theory, an individual always stays in a field/psychological field. In this field, there is a goal that the individual wants to reach, but there is always hinderance/challenge to reach it. If the individual succeed in reaching the goal, then he/she will enter a new psychological field in which there are new goals with new hinderances, etc. In teaching, the goal has to be selected from the meaningful one for the students and is formulated clearly. Learning material has to be suitable for the learners.

c. Gestalt Psychology (wholeness)

$\rightarrow$ Proponents : Wertheimer, Kurt Lewin, etc.

$\rightarrow$ This theory stresses on wholeness and integrity.

In this Gestalt teaching, learning has to start from the wholeness and then continues to the parts, so the students are required to be able to understand (insight).

An understanding about human existance theories is very important for the teachers so that in managing the learning process he/she can prepare strategies, models, methods, and instructional medias which are more accurate so that the teaching runs effectively and the students can develop their potentiality optimally.

C. Review for Safe School for Children

The term safe school is a description of a

school with peaceful condition psychologically/spiritually and physically, so that the daily condition of school gives safety feeling, peaceful for the people in the place (students, teachers, workers). In this relation, in the regulation of the ministry of education and culture of Republic of Indonesia No. 82 of 2015 on prevention and solution for violence in the school environment it is stated that violation act is a behavior which is done physically, psychologically, sexually, in network, or through course book which reflects aggressive act and attack which occur at school and causes fear, trauma, damages to things, injuries, disability, and or death. Thus, from that definition, it can be stated that safe school is a school which can suppress or eliminate violnce physically, and psychologically, spiritually, so that the school can give the feeling of safety and comfort to the people of the school continually.

On the other side, [3] stated that a Safe School is a school that recognizes and protects childrends' rights by providing condition and environment that guarantee learning process health, safety, and security of the children every time. Safe school in this case has 7 (seven) characteristic as follows: (1) provides condition and environment that guarantee learning process health, safety, and security of the children every time, (2) recognizes and respects childrens' rights not only as students, but also the right to be healthy, (3) the students get the right for having the chance to play and to do joyful activities between learning processes, (4) the right to be protected from danger and criminal actions, (5) the right to express views and opinions freely, (6) right to participate in making decicion according their capacity, (7) clean, green, beautifuul shady school 
with students who are healthy and fit and who always show clean and healthy behavior.

[4] stated that Safe School is a school that is capabe of creating a situation in which a person is free from danger and fear. Thus, a safe school is an educational institution which the people who are free from danger both internally and externally. It is pointed that at least there are sixteen characteristic of a safe school as follows.

1. Free from intimidation and bullying both from the environment and outside of the school.

2. Free from a sentimental feeling which is ethnic, religious, racial, and intergroup hatred (SARA) in nature.

3. Free from the effect of drug and hot drinks

4. Free from ciggarette and smoking

5. Free from pornography and porn action

6. Free from sexual harassment both from inside and outside of the school

7. Free from exploitation both from inside and outside of the school

8. Free from anxiety for the loss of something or the things which are brought to school

9. Free from ideologies which the not conform to religious, cultural teachings and social life values both which come from inside and outside of the school

10. Safe from natural disaster, earthquake and tsunami, volcanic erruption, hurricanes, flood, and landslide, drought, forest and land fire, safe from non-natural disasters (diseases, technological malpractices, hunger), safe from social disasters (social unrest, social conflict)

11. Free from practices of vandalism and visual violance (graffiti) in the school environment

12. Having infrastructures and facilities which are adequates to guarantee the safety feeling of all people in the school (such as having fences and gates which can be lock, glass windows which are not breakable, etc)

13. Having school regulations which are aggreed upon by all people of the school and can be reinforced effectively

14. Having training for prevention and reduction of disasters

15. Having securities who can do their duties well

16. Having good relation with polices, armforces, public figures, and religious figures, and other organization that support school safety program.

The two references above stress that a safe school has the concept of giving safe and secured feeling physically and psychologically/spiritually. Such safety feeling can have a significant effect on the creation of condition/atmosphere of condusive school (secure, comfortable, and joyful). The atmosphere or condition of the school can give the feeling of comfort and security to learn. A school or a classroom that is comfortable for students will also be able to give a positive impact on learning achievement and learning satisfaction [4]. The teaching process at the schoolt is implemented actively, inspiratively, pleasantly, and challenges as well as motivates the students to participate actively and gives room for initiative, creativity, and autonomy according to aptitude, interest and physical and psychological deveelopment of children (PP 19, 2005 and Permendiknas 41/2007). Thus, the teaching process which describes an interaction which is I2JCM: interactive, inspirative, joyful, challenges and motivates the students to participate actively can contribute to the development of a healthy school. Thus, it can be stated that a healhty school is a school that can give secure, comfortable, and joyful feelings to the people in the school (students, teachers, workers) consistently and sustainably so that they can reach learning achievement, performance achievement optimally accoding to their potentiality and finally satisfying for all stickholders.

On the national education day (Hardiknas) on the 2nd of May 2016 [5], the Minister of education and culture, Anies Baswedan stated that a holistic skill that is needed by Indonesian children in the $21 \mathrm{st}$ century consists of three components, namely character quality, literacy ability, and competency. Character consists of two parts. First is moral character, something that we often talk about. The moral character includes Pancasila values, faith, submission to God, integrity, honesty, justice, emphaty, solidarity, politeness. The second and not less important is performance character. Performance character includes hardworking, perseverence, curiousity, initiative, ability to adapt, and leadership. We want Indonesian children to develop the two parts of this character in balance. We don't want Indonesian children to become honest but lazy, or diligent but indolent. This character balance can 
become a guide in facing the rapid changing environment.

Basic literacy ability is the component of ability of the $21^{\text {st }}$ century that needs to be considered next. Basic literacy enables children to master science and to have the skill to apply it in their daily life. If so far we focus on reading, writing, and arithmathic literacy which we still have to strengthen, now we also need to consider science literacy, technology literacy, financial literacy, and culture literacy. Finally and not less in important is competency component. The $21^{\text {st }}$ century requires Indonesian children to be able to face complex and nonstructured problems. Then they need competency, creativity, critical thinking, and problem solving, communicaton and collaboration abilities.

\section{Review On Safe School For Teachers}

According to [6] and [7], teachers have to have abilities or competencies that are adequate. The competencies consist of personal, pedagogical, professional, and social competencies. The four competencies can be described in detail as follows. In Act No. 14/2005 Article 1, it is stated that a teacher is a professional educator with the major duties to teach, to guide, to direct, to train, and to evaluate the students in early child education in the formal educational system, elementary education, and high school education.

Furthermore, related to a professional teacher, in article 2 act 14/2005 it is stated that teacher profession and lecturer profession become special professions that are done based on the following principles.

(1) Having aptitude, interest, and call, idealism

(2) Having commitment to improve the quality of education, faith, and noble character

(3) Having academic qualification and educational background according to the field

(4) Having competency which are needed according to field

(5) Having responsibility for the implementation of professional duties

(6) Making an income whih is determined according to performance achievement

(7) Having an opportunity to develop professionalism in a sustainable way by life long education
(8) Having law protection that guarantee the security in doing the professional duties and

(9) Having a professional organization that has the authority to relugate the teacher professional duties.

Based on the nine teacher professional principles, it can be concluded that the professional priciples no 1, 2, 5, 8, 9 still need to be considered for a more intensive study, because the five professional principles have not got enough attention from various parties and need to be studied in depth. On the other hand, the principles can become protection for the teachers in performing their noble duties as educators of the children of the nation.

If it is interpreted in a meaningful way, the content of principle (1) about teachers having to have a call and idealim, it can be interpreted that as long as in implementing education for the children the teacher bases his/her practice on idealism, sincerity, and persecuting them.

It is assumed that the cases of the criminalizations of teachers that occurred in recent decades had a significant effect on the teacher's responsibility in educating the children of this nation to become people or human resources who are highly competitive and strong characters who can compete in the globalization battle field. If this is neglected and let to occur continuosly, we are afraid that in the future the educators/ teachers do not care or escape themselves from the responsibilities for the children's character education, that in the future it will be more difficult to find childern with the character characteristics such as honest, ethical, disciplined, responsible, preserverent, never giving up, strong mentality, etc. In fact, only human resources with strong characters like those that can be expected to build this nation in the future.

We often see children who are spoiled, lazy, unethical, dishonest, who want to enjoy things easily, afraid of life challenges, do not like to read and learn, consumptive, like parties, and some other negative behaviors. Now, it is very rare we meet students who make use of their time to read/ learn. Everywhere, we see students sitting, not reading any books, but all only are holding mobile phones. We have been accupied by Information and Communication Technology. 
One of the many responsibilities of a professional teacher is the responsibility to master 10 core pedagogic competencies which consist of :

1. Knowing very well the learner's physical, moral, social, cutural, and emotional, characteristics

2. Knowing very well learning theories and principles of teaching which are educating

3. Developing a curriculum that is related to the development of the subjecs taught

4. Implementing developmental activities

5. Making use of ICT for implementing educating developmental activities

6. Facilitating students' potentialityity development to actualize various potentialityities that they have

7. Communicating effectively, emphaticall, and politely with students

8. Implementing learning process and learning achievement evaluations

9. Making use of the evaluation results and an evaluation for the purpose of teaching.

10. Doing reflective actions to improve teaching quality.

In the light of the discussion in points $\mathrm{C}$ and $\mathrm{D}$ above, we can investigate that if the teachers (educators) want to feel safe in doing their duties in educating the children of the nation, there is no other choice , except they have to comform to regulation, guidelines, and codes of ethics about the year major duties and function. And if the teachers have consistently and consiquently do the major duties and function, then we can guarantee that the teachers and the students will be protected simultaniously.

\section{CONCLUSION}

Based on the discussion in section II above, it can be stated that to make a safe school for students and teachers become a reality there have to be some efforts to make them and others aware and understand that to educate students (children of the nation) to become strong character children, of high quality and competitiveness not only the students which need to be protected for safe feeling, but the teachers (educators) also need protection, since the teachers often discriminalize which result in fear or unsafe feeling, then we are afraid that they will be free from the responsibility as educators and only perform the task as teachers, that is, they only do the transactional task of science and technology for the students if this occurs continually, then it will be more difficult to teach the children of the nation of strong character, moral character, literacy character, and competency character.

To prevent violance at schools some things as follows should be done. (1) It is very important to develop communication or communication forums among stickholders such as public figure, police, PGRI, and MKKS. With the formation of such communication forums, it is expected that criminal cases will not reoccur at schools, and if there are cases, then they can be resolved in a family way, (2) there needs to be an effort to develop and implement Local Wisdom based School Management Model to develop a school culture with character and harmony.

\section{REFERENCES}

[1] Agung, A. A. Gede. 2012. Pengembangan Guru Profesional yang Tersertifikasi. Singaraja: Undiksha.

[2] Agung, A. A. Gede. 2013. Landasan Pendidikan. Singaraja: FIP Undiksha.

[3] Panduan Teknis Rehabilitasi Sekolah Aman dengan Dana Alokasi Khusus (DAK) Pendidikan Tahun 2011. Jakarta: Badan Nasional Penanggulangan Bencana

[4] Degeng, Nyoman S. 2013. Ilmu Pembelajaran "Klasifikasi Variabel untuk Pengembangan Teori dan Penelitian". Bandung: Arasmedia Kalam Hidup.

[5] Kemdikbud RI. 2016. Pidato Menteri Pendidikan dan Kebudayaan RI pada Hari Pendidikan Nasional, 2 Mei 2016. Jakarta: Kemdikbud RI.

[6] Undang-Undang Nomor 20 Tahun 2003 tentang Sistem Pendidikan Nasional. Jakarta: Depdikbud RI.

[7] Undang-Undang Nomor 14 Tahun 2005 tentang Guru dan Dosen. Jakarta: Depdikbud RI. 